\title{
MUTU IKAN CAKALANG (Katsuwonus pelamis L) ASAP YANG DIRENDAM DENGAN LARUTAN KULIT BUAH MANGGIS (Gracinia mangostana Linn).
}

\author{
Septian Gedoan Bentalen ${ }^{1}$, Hens Onibala ${ }^{2}$ dan Netty Salindeho ${ }^{2}$ \\ ${ }^{1)}$ Mahasiswa pada Program Studi Teknologi Hasil Perikanan FPIK Unsrat Manado \\ ${ }^{2)}$ Staf pengajar pada Program Studi Teknologi Hasil Perikanan FPIK Unsrat Manado \\ Email: Septianbentalen@yahoo.com
}

\begin{abstract}
The purpose of this study was to determine the quality of smoked skipjack (Katsuwonus pelamis L) smoke pre-treated in a solution of mangosteen peel with a concentration of 3,4 and 5\%, with various soaking time, then stored and observed at $0,3,6$, and 9 days. The results showed that the highest value of total plate count (TPC) was found in the fish sample storage for 9 days, soaking with a concentration of $3 \%$ for 30 minutes. Meanwhile, the lowest TPC value was discovered for the fish samples that did not undergo storage, and immersed in a solution of $5 \%$ for 30 minutes. Furthermore, the highest TVB value (Total Volatile bases) was detected in fish samples soaked with $3 \%$ solution of the mangosteen for 15 minutes $(59.22 \mathrm{mg} \mathrm{N} / 100 \mathrm{~g})$ while the lowest value obtained on the fish sample marinated with $5 \%$ concentration for 15 minutes and did not experience storage $(5.04 \mathrm{mg} \mathrm{N} / 100 \mathrm{~g})$.
\end{abstract}

Keyword: $\quad$ Katsuwonus pelamis L, mangosteen, Gracinia mangostana L

Sub sektor perikanan dan pertanian merupakan andalan utama sumber pangan dan gizi bagi masyarakat Indonesia. Manggis (Gracinia mangostana L.) merupakan tanaman tahunan yang hidup di daerah tropis, buahnya memiliki rasa manis dan sedikit asam. Manggis merupakan tumbuhan fungsional karena sebagian besar dari tumbuhan tersebut dapat dimanfaatkan sebagai obat. Di beberapa negara maju, ikan telah dikenal sebagai suatu komoditi yang populer karena memiliki rasa yang enak dan baik untuk kesehatan. Tujuan penelitian ini. Untuk mengetahui mutu ikan cakalang (Katsuwonus pelamis L) asap yang diberi larutan kulit Manggis. Manfaat penelitian ini diharapkan dapat memberikan informasi tentang kajian mutu ikan cakalang asap yang diberi larutan kulit Manggis dengan konsentrasi 3, 4 dan $5 \%$. Hasil yang diperoleh dari ikan cakalang asap yang diberi larutan kulit buah Manggis memiliki nilai TPC tertinggi terdapat pada hari ke 9 konsentrasi 3\% lama perendaman 30 menit dengan nilai 5,055 koloni/gram. Sedangkan Nilai terendah 0 hari dengan konsentrasi 5\% lama perendaman 30 menit dengan nilai 4,25 koloni/gram. Kemudian nilai TVB nilai tertinggi terdapat pada hari ke 9 konsentrasi 3\% lama perendaman 15 menit dengan nilai $59,22 \mathrm{mg} \mathrm{N} / 100 \mathrm{gr}$. sedangkan nilai terendah 0 hari dengan konsentrasi 5\% lama perendaman 15 menit dengan nilai 5,04 mg N/100 gr.

Kata Kunci: Mutu cakalang asap, Manggis, Gracinia Mangostana Linn.

\section{PENDAHULUAN}

Sub sektor perikanan dan pertanian merupakan andalan utama sumber pangan dan gizi bagi masyarakat Indonesia. Di beberapa negara maju, ikan telah dikenal sebagai suatu komoditi yang populer karena memiliki rasa yang enak dan bagus untuk kesehatan. Ikan merupakan sumber asam lemak tak jenuh, taurin dan asam lemak omega-3, terutama untuk jenis ikan seperti tuna, tongkol, kembung, dan lemuru. Komponen tersebut telah terbukti dapat mencegah penyumbatan pembuluh darah (Arteriosclerosis), oleh karena itu banyak orang berpendapat untuk meningkatkan konsumsi protein harian (Daily protein intake) terutama yang berasal dari ikan (Winarni $d k k ., 2003$ ).
Ikan juga merupakan salah satu bahan makanan yang tidak asing lagi bagi masyarakat Indonesia, bahan makanan ini memiliki kelebihan yaitu mengandung asam amino esensial yang diperlukan oleh tubuh, disamping itu nilai biologisnya mencapai $90 \%$ dengan jaringan pengikat sedikit sehingga mudah dicerna, selain itu harganya jauh lebih murah dibandingkan sumber protein lainnya (Adawyah, 2007).

Pengasapan merupakan cara pengolahan atau pengawetan dengan memanfaatkan kombinasi perlakuan pengeringan dan pemberian senyawa kimia alami dari hasil pembakaran bahan bakar alami. Melalui pembakaran akan terbentuk senyawa asap dalam bentuk uap dan butiran tar serta 
dihasilkan panas. Senyawa asap tersebut menempel pada ikan dan terlarut dalam lapisan air yang ada di permukaan tubuh ikan, sehingga terbentuk aroma dan rasa yang khas pada produk dan warnanya menjadi keemasan atau kecoklatan (Wibowo, 1996).

Manggis (Gracinia mangostana Linn.) merupakan tumbuhan yang berasal dari daerah Asia Tenggara meliputi Indonesia, Malaysia, Thailand dan Myanmar. Manggis merupakan tumbuhan fungsional karena sebagian besar dari tumbuhan tersebut dapat dimanfaatkan sebagai obat. Akan tetapi, banyak yang tidak mengetahui jika kulit buah Manggis memiliki khasiat. Kulit buah Manggis yang selama ini dibuang sebagai limbah setelah habis menyantap daging buah, ternyata memiliki segudang manfaat penting bagi kesehatan. Di dalam kulit buah Manggis kaya akan antioksidan seperti xanthone dan antosianin (Moongkandi, et al., 2004) Berbagai penelitian menunjukkan, senyawa xanthone yang terdapat di dalam kulit buah Manggis memiliki sifat sebagai anti diabetes, anti kanker, anti peradangan, meningkatkan kekebalan tubuh, anti bakteri, anti fungi, dan dapat digunakan sebagai pewarna alami. Xanthone di dalam kulit buah Manggis yang bersifat sebagai anti diabetes telah dibuktikan oleh seorang peneliti di Jepang, yang dapat menurunkan kadar glukosa darah pada tikus percobaan dengan kasus diabetes mellitus tipe II.

\section{METODOLOGI PENELITIAN}

Penelitian ini dilaksanakan di Laboratorium Teknologi Penanganan dan Pengolahan Hasil Perikanan Universitas Sam Ratulangi Fakultas Perikanan dan Ilmu Kelautan Manado. Penelitian ini telah dilaksanakan mulai dari bulan Mei sampai Agustus 2016.

\section{Bahan Penelitian}

Bahan yang digunakan dalam penelitian ini antara lain Bahan baku utama yang dijadikan sampel untuk penelitian ini yaitu produk ikan Cakalang (Katsuwonus pelamis L.) yang dibeli dari pasar Bahu Manado dan buah Manggis yang dibeli dari pasar Bersehati Manado. Bahan kimia yang digunakan Nutrient Agar (NA), akuades, $\mathrm{NaCl}$, larutan TCA (Trikhloroacetic Acid) $7 \%$, larutan Kalium Karbonat $\left(\mathrm{K}_{2} \mathrm{CO}_{3}\right)$ jenuh, TCA $7,5 \%$, Larutan Indikator (methil red dan bromo cresol green),
Asam Borat $\left(\mathrm{H}_{3} \mathrm{BO}_{3}\right)$, Asam Klorida ( $\mathrm{HCl} \mathrm{0,02}$ $\mathrm{N})$, dan Vaselin.

\section{Alat Penelitian}

Peralatan yang digunakan adalah: timbangan analitik, oven, Erlenmeyer, Magnetic stirrer, tabung reaksi, spatula, pipet steril, beaker glass, gelas ukur, cawan petri, autoclave, laminar flow, inkubator, wadah penyimpanan/ piring, pisau, tissue, mortar, baker glass, gelas ukur, kertas saring whatman no.2, cawan conway, pipet, corong kaca, cawan porselen dan alat penjepit.

\section{Tata Laksana Penelitian}

1. Pengambilan sampel ikan cakalang.

a. Ikan cakalang di beli dari pasar Bahu Manado sebanyak 6 ekor yang berukuran \pm $1 \mathrm{~kg}$. Agar ikan tetap terjaga mutunya ikan ditempatkan ke dalam cool box dan diberi es lalu dibawa ke laboratorium penanganan dan pengolahan hasil perikanan untuk diproses pengasapan.

b. Sebelum dilakukan pengasapan, ikan disiangi, dimana insang dan isi perut dibuang lalu dicuci dengan air bersih.

c. Kemudian ikan dilakukan pengasapan.

2. Pembutan larutan kulit buah Manggis.

a. Manggis yang di beli dari pasar Bersehati di filet, sebanyak 12 filet, sebelum dibuat ekstrak disortir terlebih dahulu, Manggis yang masih terlihat segar diambil untuk dibuat larutan.

b. Setelah mendapatkan Manggis yang baik langkah selanjutnya adalah pencucian buah Manggis. Setelah buah Manggis bersih belah buah Manggis tersebut satu-persatu dan kemudian pisahkan isinya.

c. Kulit Manggis yang sudah dipisahkan dari isinya kemudian dipotong halus-halus dengan menggunakan gunting.

d. Keringkan kulit buah Manggis selama 3 hari pada suhu ruang $\left(28-30^{\circ} \mathrm{C}\right)$.

e. Kulit Manggis yang sudah kering kemudian dihaluskan dengan menggunakan blender. Kemudian kulit buah Manggis yang sudah berbentuk bubuk disimpan dengan menggunakan kantong plastik.

\section{Perendaman ikan cakalang dengan larutan kulit buah Manggis.}

Larutan manggis yang sudah berbentuk bubuk ditimbang sebanyak 30, 40 dan 50gr. 
kemudian siapkan ikan cakalang yang sudah difilet sebanyak 12 filet untuk direndam dengan larutan kulit buah manggis. Sebelum melakukan perendaman larutan kulit manggis dimasukan ke dalam air dan disaring dengan menggunakan kain saring. tiap 30gr ekstrak manggis dilarutkan ke dalam air sebanyak $1000 \mathrm{ml}$, begitu pula dengan 40gr dan 50gr masingmasing dilarutkan ke dalam air sebanyak 1000 ml. Perendaman ikan cakalang dilakukan dengan waktu yang berbeda yaitu 15 menit dan 30 menit.

\section{Pengasapan ikan}

Proses pengasapan ikan berlangsung selama 4-5 jam dengan suhu pengasapan 70$80^{\circ} \mathrm{C}$ sesudah proses pengasapan, ikan didinginkan selama 30 menit untuk diuji lanjut. Parameter yang digunakan untuk uji lanjut adalah: uji TPC dan TVB-N dengan konsentrasi larutan kulit buah manggis sebanyak 3, 4 dan $5 \%$.

\section{Perlakuan Dan Rancangan Percobaan}

Penelitian ini dirancang dengan menggunakan rancangan acak lengkap (RAL) yang disusun secara faktorial $3 \times 2 \times 4 \times 2$ dan setiap perlakuan diberikan dua kali ulangan. Rancangan acak lengkap menurut Steel dan Torrie (1991) digunakan apabila satuan percobaannya homogen, artinya keragaman antar satuaan percobaan kecil sekali dan untuk mengelompokkannya ke dalam kelompok tidak memberikan manfaat. Perlakuan yang dilakukan dalam penelitian ini adalah sebagai berikut:

Faktor $\mathrm{A}=$ pemberian kosentrasi ekstrat kulit buah manggis

$\mathrm{A}_{1}$ : konsentrasi $3 \%$

$\mathrm{A}_{2}$ : konsentrasi $4 \%$

$\mathrm{A}_{3}$ : konsentrasi $5 \%$

Faktor $\mathrm{B}=$ lama Perendaman

$\mathrm{B}_{1}: 15$ menit.

$\mathrm{B}_{2}: 30$ menit.

Faktor $\mathrm{C}=$ lama penyimpanan

$\mathrm{C}_{1}: 0$ Hari.

$\mathrm{C}_{2}: 3$ Hari.

$\mathrm{C}_{3}: 6$ Hari.

$\mathrm{C}_{4}: 9$ Hari.

\section{Analisa TPC (Total plate count)}

Total bakteri dianalisa dengan menggunakan metode sebar (Ijong 2003). Metode ini bersifat kuantitatif, dengan menghitung jumlah populasi mikroba yang ada dalam bahan pangan ikan. Mikroba yang tumbuh pada metode ini sebagian besar bersifat aerobik. Prosedur pengujiannya ialah sebagai berikut:

1. Semua peralatan yang digunakan dalam analisa mikrobiologis disterilkan terlebih dahulu dengan menggunakan autoclave pada suhu $121^{\circ} \mathrm{C}$, dengan tekanan 15 psi, selama 15 menit.

2. Disiapkan tabung reaksi yang telah diberi kode, lalu diisi dengan $9 \mathrm{ml} \mathrm{NaCl} 0,9 \%$, kemudian disterilkan.

3. Sampel ditimbang $10 \mathrm{~g}$, ditambah $90 \mathrm{ml}$ larutan Nacl 0,9\% kemudian diblender sampai homogen. Sampel ini merupakan suspense pengencer $10^{-1}$.

4. Selanjutnya diambil $1 \mathrm{ml}$ suspense dari pengencer di atas dan dipindahkan ke dalam tabung reaksi lain yang telah berisi $9 \mathrm{ml}$ $\mathrm{NaCl}$ steril pengencer $10^{-2}$. dan diperoleh $0,9 \%$ steril. Demikian seterusnya sampai tingkat pengencer $10^{-5}$.

5. Diambil NA yang telah disterilkan dan masih dalam keadaan hangat (suhu kira-kira $37-45^{\circ} \mathrm{C}$ ) secara aseptik sebanyak $15 \mathrm{ml}$ NA dituangkan ke dalam cawan petri yang telah diberi kode, lalu tunggu sampai media tersebut mengeras.

6. Setelah NA mengeras, dari setiap pengenceran diambil masing-masing $1 \mathrm{ml}$ suspensi dan dipindahkan ke dalam media NA yang telah diberi kode, lalu dengan menggunakan batang penyebar gelas steril, suspense tersebut disebarkan di seluruh permukaan media secara merata. Sementara penyebaran suspense dilakukan, cawan petri diputar perlahan-lahan.

7. Semua cawan petri dimasukkan ke dalam inkubator dengan posisi terbalik, dan diinkubasi selama 24 jam pada suhu $37^{\circ} \mathrm{C}$.

8. Kemudian dihitung jumlah koloni pada masing-masing petri. Untuk mendapatkan hasil yang baik maka setiap pengenceran dibuat duplo. Jumlah koloni yang dihitung pada cawan petri yaitu antara 30-300 koloni dan dalam keadaan koloni bebas.

9. Setelah itu, jumlah yang diperoleh dikalikan dengan satu per tingkat pengenceran.

\section{Analisa TVB-N (Total Volatile Bases)}

Suwetja, (1993) Metode analisa Total Volatile Base (TVB) ditetapkan dengan metode Conway: 
1. Lima (5) g daging ikan, dihancurkan dengan menambahkan $10 \mathrm{ml}$ larutan TCA 7,5\%.

2. Setelah hancur rata, sampel ikan disaring dengan kertas saring (no.2-3).

3. Sebanyak $1 \mathrm{ml}$ larutan asam borat $\left(\mathrm{H}_{3} \mathrm{BO}_{3}\right)$ $1 \%$ dan beberapa tetes larutan indikator (methyl red dan bromo cresol green) dipipet ke inner chamber.

4. Kemudian $1 \mathrm{ml}$ larutan ekstrak daging ikan dipipet ke outer chamber.

5. Setelah itu, penutup cawan yang permukaannya telah diolesi rata dengan vaselin, diletakkan pada rumahnya dengan posisi sedikit terbuka.

6. Selanjutnya, $1 \mathrm{ml} \mathrm{K}_{2} \mathrm{CO}_{3}$ jenuh dipipet ke outer chamber bagian lain,

7. Kemudian cawan ditutup rapat dan diputar perlahan sampai larutan sampel bercampur dengan $\mathrm{K}_{2} \mathrm{CO}_{3}$ jenuh. Blanko dibuat dengan, mengganti larutan ekstraksi daging ikan dipakai larutan TCA.

8. Cawan disimpan dalam suhu kamar selama 24 jam. Dititrasi bagian inner chamber dengan menggunakan larutan asam klorida $(\mathrm{HCl}) 0.02 \mathrm{~N}$. Titik akhir titrasi adalah pada saat asam borat kembali berwarna merah muda kemudian dicatat berapa banyak $(\mathrm{ml})$ asam klorida yang digunakan untuk mentitrasi.

\section{HASIL DAN PEMBAHASAN}

\section{Analisa nilai TPC (Total plate count).}

Dari hasil penelitian menjelaskan bahwa pengaruh lama penyimpanan ikan cakalang asap yang diberi larutan kulit buah Manggis disimpan pada suhu ruang $\left(28-30^{\circ} \mathrm{C}\right)$ jumlah koloni semakin lama semakin meningkat. Meningkatnya jumlah bakteri disebabkan karena mutu produk ikan asap mengalami penurunan mutu akibat penyimpanan pada suhu ruang. Menurut Berhimpon (1995) bahwa meningkatnya jumlah koloni bakteri berhubungan dengan meningkatnya nilai $\mathrm{pH}$ produk selama penyimpanan dan juga temperatur ruang penyimpanan produk (25$30^{\circ} \mathrm{C}$ ). llyas (1983), pertumbuhan bakteri pada ikan sangat dipengaruhi oleh suhu, semakin rendahnya suhu ikan semakin lambat pertumbuhan bakteri. Selama penyimpanan akan terjadi perubahan dekomposisi baik oleh flora bakteri maupun oleh enzim proteolitik. Ketersedian oksigen juga membatasi pertumbuhan mikroba akan terhambat. Pada penyimpanan 9 hari terjadi peningkatan nilai koloni bakteri, hal ini disebabkan bakteri dan kapang mulai bertumbuh dan berkembang biak. Hal ini dipertegas oleh Buckle $d k k$. (1985), bahwa pada tahap awal pertumbuhan mikroorganisme belum terjadi pembelahan sel. Selanjutnya setelah mampu beradaptasi dengan lingkungannya yang baru, sel-sel bakteri akan tumbuh dan membelah secara eksponsil sampai jumlah yang maksimum.

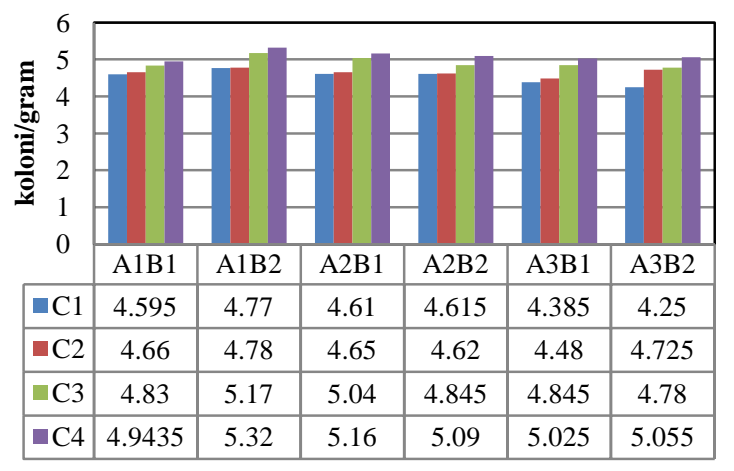

Gambar 1. Histogram TPC (Total plate count).

Pada histogram di atas menjelaskan kombinasi perlakuan $A_{1} B_{1}$ dari 0 hari sampai hari ke 9 nilai pertumbuhan bakteri mengalami peningkatan. nilai rata-rata pada 0 hari adalah 4,59 koloni/gram kemudian nilai rata-rata hari ke 3 adalah 4,66 koloni/gram, kemudian nilai rata-rata pada hari ke 6 adalah 4,83 koloni/gram, begitu pula pada hari ke 9 nilai rata-rata pertumbuhan koloni meningkat yaitu 4,94 koloni/gram. Pada kombinasi perlakuan $\mathrm{A}_{1} \mathrm{~B}_{2}$ dari 0 hari sampai hari ke 9 jumlah bakteri mengalami peningkatan. pada 0 hari nilai ratarata adalah 4,77 koloni/gram kemudian, pada hari ke 3 niali rata-rata koloni 4,78 koloni/gram kemudian, pada hari ke 6 mengalami peningkatan yaitu dengan nilai 5,17 koloni/ gram dan kemudian pada hari ke 9 nilai bakteri juga mengalami peningkata dengan nilai ratarata 5,32 koloni/gram. Pada kombinasi perlakuan $\mathrm{A}_{2} \mathrm{~B}_{1}$ nilai rata-rata dari 0 hari sampai hari ke 9 nilai koloni mengalami peningkatan. Pada 0 hari nilai rata-rata adalah 4,61 koloni/ gram kemudian, pada hari ke 3 mengalami peningkatan dengan nilai 4,65 koloni/gram. Kemudian pada hari ke 6 nilai koloni mengalami peningkatan dengan nilai rata-rata 5,04 koloni/gram, kemudian pada hari ke 9 nilai koloni juga mengalami peningkatan dengan nilai 5,16 koloni/gram. Pada kombinasi perlakuan $\mathrm{A}_{2} \mathrm{~B}_{2}$ dari 0 hari sampai hari ke 9 nilai koloni mengalami peningkatan. nialai ratarata pada 0 hari adalah 4,61 koloni/gram 
kemudian, pada hari ke 3 nilai koloni mengalami peningkatan dengan nilai rata-rata 4,62 koloni/gram kemudian pada hari ke nilai rata-rata koloni adalah 4,84 koloni/gram, kemudian pada hari ke 9 nilai koloni juga mengalami peningkatan dengan nilai 5,09 koloni/gram. Pada kombinasi perlakuan $A_{3} B_{1}$ nilai pertumbuhan koloni dari 0 hari sampai hari ke 9 juga mengalami peningkatan. Pada 0 hari nlai rata-rata adalah 4,38 koloni/gram, kemudian pada hari ke 3 nilai koloni mengalami peningkatan dengan nilai rata-rata 4,48 koloni/ gram, kemudian pada hari ke 6 nilai koloni juga mengalami peningkatan dengan nilai rata-rata 4,84 koloni/gram, kemudian begitu juga pada hari ke 9 nilai koloni juga mengalami peningkatan yaitu dengan nilai rata-rata 5,02 koloni/gram. Pada kombinsi perlakuan $\mathrm{A}_{3} \mathrm{~B}_{2}$ nilai koloni dari 0 hari sampai hari ke 9 nilai koloni mengalami peningkatan. Nilai rata-rata yang terdapat pada 0 hari adalah 4,25 koloni/ gram, kemudian pada hari ke 3 nilai rata-rata jumlah koloni adalah 4,72 koloni/gram, kemudian pada hari ke 6 nilai rata-rata jumlah koloni adalah 4,78 koloni/gram, kemudian pada hari ke 9 nilai rata-rata jumlah koloni adalah $5,05 \mathrm{koloni} / \mathrm{gram}$.

Hasil penelitian menunjukan bahwa larutan kulit buah manggis dapat menekan jumlah pertumbuhan bakteri karena jumlah bakteri dari 0 hari sampai hari ke 9 masih di bawah Standarisasi Nasional Indonesia (SNI). Berdasarkan persyaratan mutu yang dikeluarkan oleh Badan Standarisasi Nasional Indonesia (SNI 2009) jumlah bakteri maksimum untuk ikan asap adalah $5 \times 10^{5} \mathrm{koloni} / \mathrm{gram}$. Hal ini berarti bahwa produk ikan cakalang asap yang diberi larutan kulit buah manggis yang mengalami penyimpanan dari 0 hari sampai hari ke 9 masih layak untuk dikonsumsi karena jumlah bakteri pada hari ke 9 lebih rendah dibandingkan dengan Standarisasi Nasional Indonesia (SNI). Nilai pertumbuhan bakteri ikan cakalang asap yang diberi larutan kulit buah manggis pada hari ke 9 adalah $2,1 \times 10^{5}$ koloni/gram.

Berdasarkan hasil penelitian, diperoleh nilai rata-rata TVB-N ikan cakalang asap yang diberi larutan kulit buah manggis. Berdasarkan histogram diatas nilai rata-rata TVB-N pada kombinasi perlakuan $\mathrm{A}_{1} \mathrm{~B}_{1}$, nilai tertinggi terdapat pada hari ke 9 dengan nilai $59,22 \mathrm{mg}$ N/100 gr, sedangkan nilai rata-rata terendah terdapat pada 0 hari dengan nilai $41,16 \mathrm{mg}$
N/100 gr. Kemudian nilai rata-rata pada kombinasi perlakuan $\mathrm{A}_{1} \mathrm{~B}_{2}$, nilai tertinggi terdapat pada hari ke 9 dengan nilai $49,14 \mathrm{mg}$ N/100 gr, sedangkan nilai TVB-N rata-rata terendah terdapat pada 0 hari dengan nilai 31.92 mg N/100 gr. Kemudian nilai rata-rata pada kombinasi perlakuan $\mathrm{A}_{2} \mathrm{~B}_{1}$, nilai tertinggi terdapat pada hari ke 9 dengan nilai $37,8 \mathrm{mg}$ $\mathrm{N} / 100$ gr, sedangkan nilai TVB-N rata-rata terendah terdapat pada 0 hari dengan nilai 23,94 mg N/100 gr. Kemudian nilai rata-rata pada kombinasi perlakuan $\mathrm{A}_{2} \mathrm{~B}_{2}$, nilai tertinggi terdapat pada hari ke 9 dengan nilai $27,72 \mathrm{mg}$ N/100 gr, sedangkan nilai TVB-N rata-rata terendah terdapat pada 0 hari dengan nilai 17,22 mg N/100 gr. Kemudian nilai rata-rata pada kombinasi perlakuan $A_{3} B_{1}$, nilai tertinggi terdapat pada hari ke 9 dengan nilai $17,66 \mathrm{mg}$ $\mathrm{N} / 100$ gr, sedangkan nilai TVB-N rata-rata terendah terdapat pada 0 hari dengan nilai 11,34 mg N/100 gr. Kemudian nilai rata-rata pada kombinasi perlakuan $\mathrm{A}_{3} \mathrm{~B}_{2}$, nilai tertinggi terdapat pada hari ke 9 dengan nilai $8,4 \mathrm{mg}$ $\mathrm{N} / 100$ gr, sedangkan nilai TVB-N rata-rata terendah terdapat pada 0 hari dengan nilai 5,04 mg N/100 gr.

Dari hasil penelitian nilai TVB-N dapat disimpulkan bahwa ikan cakalang asap yang diberi larutan kulit buah manggis selama penyimpanan $0,3,6$ dan 9 hari masih layak untuk dikonsumsi karna nilai TVB-N masih di bawah SNI (Standar Nasional Indonesia).

Berdasarkan Standar nilai TVB-N ikan olahan (ikan yang dikeringkan dan digarami) menurut SNI 2006 adalah 100-120 mg N/100gr.

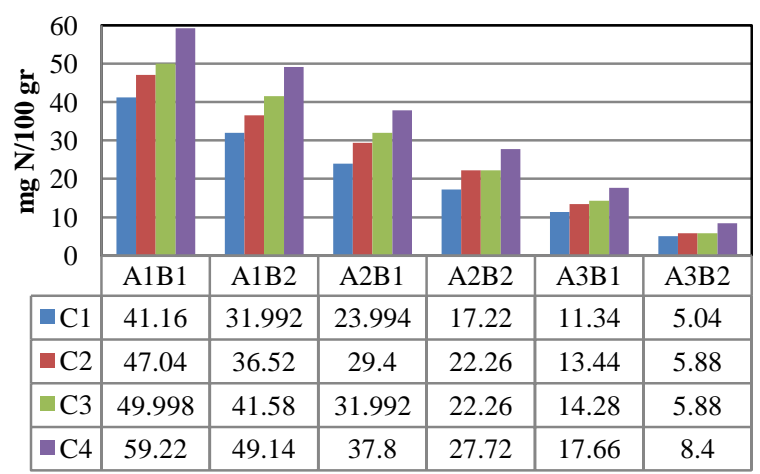

Gambar 2. Histogram nilai TVB (Total volatile bases).

Dari hasil histogram di atas dapat terlihat nilai TVB-N semakin lama ikan cakalang asap yang diberi larutan kulit buah manggis disimpan pada suhu ruanag $\left(30^{\circ} \mathrm{C}\right)$ semakin meningkat nilai TVB-N-nya. 
Meningkatnya nilai TVB-N disebabkan karena ikan mengalami kemunduran mutu. Menurut Suwetja (1993), kerja bakteri dalam merombak protein dan asam-asam amino menjadi senyawa-senyawa yang lebih sederhana untuk dapat tumbuh dan berkembang biak menghasilkan senyawa-senyawa sisa seperti $\mathrm{NH}_{3}$, trimetilamin dari senyawa-senyawa turunannya dimana senyawa-senyawa ini termasuk golongan basa-basa menguap. Nilai TVB-N sangat erat kaitannya dengan proses kemunduran mutu karena semakin tinggi nilai TVB biasanya semakin mundur nilai mutu produk tersebut. Yunizal dkk. (1998), menyatakan keadaan dan jumlah kadar TVB-N tergantung pada mutu kesegaran ikan, makin mundur mutu ikan, kadar TVB-N akan meningkat jumlahnya. Kondisi ini memberikan kesempatan yang baik untuk bakteri dapat berkembang dengan bebas, selama penyimpanan pada suhu ruang. Hal ini mungkin terjadi karena adanya senyawa-senyawa basah yang meningkat lewat perombakan protein oleh aktivitas bakteri atau mikroorganisme lainnya atau faktor lain yang mempengaruhi nilai TVB.

\section{DAFTAR PUSTAKA}

Adawyah R. 2007.Pengolahan dan Pengawetan Ikan. Penerbit Bumi Aksara. Jakarta

Berhimpon, S., 1995. Studi Pengemasan Dan Penyimpanan Ikan Asap dan Produk Olahannya. Penelitian Mandiri. Fakultas Perikanan. UNSRAT. Manado.
Bucle, K.A., R.A. Edward, G.H., Fleet, M. Wootten. 1987. Ilmu Pangan. Penerjemah Harri Purnomo dan Adiono. UI-Press. Jakarata.

Ijong F.G. 2003 Penentuan Praktikum Mkrobiologi Pangan Ikani. Fakultas Perikanan Dan Iilmu Kelatan Universitas Sam Ratungi Manado

IIyas, S, 1983. "Teknologi Refrigrasi Hasil Perikanan". Jilid 1. Teknik Pendinginan Ikan. C. V. Paripurna, Jakarta

Moongkarndi, P., Kosem, N., Kaslungka, S., Luanratana, O., Pongpan, N., dan Neungton, N. (2004). Antiproliferation, antioxidation and induction of apoptosit by Garcinia mangostana (mangosteen) on SKBR3 human breast cancer cell line. J.Ethonopharmacol. 90(1): 161-166. Diakses 23 November 2016

Steel, R.G.D. \&Torrie, J.H. 1991. Prinsip dan Prosedur Statistika Suatu Pendekatan Biometrik (Terjemahan: Bambang Sumantri). Jakarta: PT.Gramedia. Diakses 24 November 2016

Suwetja, K. I. 1993. Metode Penentuan Mutu Ikan. Jilid I. Penentuan Kesegaran. Fakultas Perikanan dan Ilmu Kelautan. Universitas Sam Ratulangi. Manado

(SNI) Standar Nasional Indonesia. 2009. (BSN) Badan Standarisasi Nasional. 7388 Batas maksimum cemaran mikroba dalam pangan. Jakarta.

Wibowo, S. 1996. Industri Pengasapan Ikan. Penebar Swadaya. Jakarta.

Winarni, T., Swastawati, F., Darmanto, Y. S., dan Dewi, E. N. 2003. Uji Mutu Terpadu pada Beberapa Spesies Ikan dan Produk Perikanan di Indonesia. Laporan Akhir Hibah Bersaing XI Perguruan Tinggi. Universitas Diponegoro.

Yunizal, 1998 Penanganan ikan segar. Jakarta. Instalasi penelitian perikanan Laut sipil. 